\title{
Effect of nano based seed treatment insecticides on seed quality in Pigeonpea
}

\author{
B.N. Raghu, Basave Gowda, S. N. Vasudevan, Sangeeta I. Macha, Sharan Gouda \\ Hiregoudar and Arun Kumar Hosmani
}

Department of Seed Science and Technology, College of Agriculture, University of Agricultural Sciences, Raichur584104 (Karnataka), INDIA

*Corresponding author. E-mail: raghubn123@gmail.com

Received: August 8, 2016; Revised received: February 9, 2017; Accepted: May 12, 2017

Abstract: A laboratory experiment was conducted to know the effect seed treatment with nano insecticides on seed quality of pigeonpea (Cajanus cajan (L.) Millsp.) cv. TS3R. This study was conducted to evaluate the effect of macro and nano insecticides on seed germination and vigour of Pigeonpea. Different recommended seed treatment insecticides viz, malathion, fenvalerate, emamectine benzoate, thiodicarb, sweet flag and neem seed kernel powder insecticides were synthesized to nano form using high energy planetary ball mill. The Pigeonpea seed were treated with different nano insecticides i.e., 10-90 per cent reduction in actual dosage. Among the different treatments studied, seed treated with nano malathion 50 per cent lesser than normal dosage, fenvalerate 60 per cent lesser, thiodicarb 10 per cent lesser, emamectine benzoate 30 per cent lesser, sweetflag 70 per cent lesser, neem seed kernel powder 40 per cent lesser than actual recommended dosage gave significantly higher seed germination (98.0, 98.67, 98.67, 97.0, 99.0 and 98.67 percent) ,less number of abnormal seedlings (1.0, 0.33, 1.0, 1.0, 1.0 and 0.33 per cent), shoot length $(10.13,9.00,11.47,9.50,10.90$ and $10.87 \mathrm{~cm})$, root length $(12.56,12.93,12.83,12.6011 .50$ and $13.00 \mathrm{~cm})$, seedling dry weight $(85.73,87.40,88.47,87.70,88.60$ and $88.27 \mathrm{~g})$ and seedling vigour index (2223, $2164,2397,2143,2217$ and 2354) as compared to untreated seeds and macro insecticides. Therefore, it is very clear that nano based insecticides has a significant $(0.1 \%)$ impact on the seed quality improvement.

Keywords: Nano insecticides, Pigeonpea, Seed treatment and Seed quality

\section{INTRODUCTION}

Pigeonpea is one of the major pulse crops of the tropics and sub-tropics. It is commonly known as redgram, tur, arhar in India. Pigeonpea ranks sixth in area and production in comparison to other grain legumes such as beans, peas and chickpea (Korishettar et al., 2016). Nanotechnology is a science that nowadays has widely application in almost all the technology field like chemical, manufacturing, medical, agricultural sector (Manchikanti and Bandopadhyay, 2010). Nanomaterials because of their tiny size show unique characteristics. They can change physic-chemical properties compared to their macro materials, they have a great surface area than macro materials. Because of these larger surface areas, their solubility and high surface reactivity (Nel et al., 2006).

Nanoparticles help to produce new pesticides, insecticides and insect repellants (Owolade et al., 2008). The use of nanoparticles in the growth of plants and for the control of plant diseases is a recent practice studied. The effect of mixtures of nano-SiO2 and nano-TiO2 on soybean seeds and they found that the mixture of nanoparticles increases nitrate reductase in soybean increasing its germination and growth (Prasad et al, 2009). There are reports that nanomaterials on higher plants had both positive and negative effects (Laurent S. et al, 2008). Experts feel that the potential benefits of nanotechnology for agriculture, food, fisheries and aquaculture need to be balanced against concerns for the soil, water, and environment and the occupational health of workers. Raising awareness of nanotechnology in the agri-food sector, including feed and food ingredients, intelligent packaging and quick-detection systems, is one of the keys to influencing consumer acceptance (Carmen et al. 2003). On the basis of only a handful of toxicological studies (Hong et al., 2005), concerns have arisen regarding the safety of nanomaterials, researchers and companies will need to prove that these nanotechnologies do not have more of a negative impact on the environment. Agri-food nanotechnology is multidisciplinary in nature. Nanotechnology application to the agriculture and food sectors is relatively recent compared with its use in drug delivery and pharmaceuticals. Nanotechnology has the potential to protect plants, monitor plant growth, detect plant and animal diseases, increase global food production, enhance food quality, and reduce waste for "sustainable intensification" ( Locke J.M. et al., 2000) . In order to exploit the potential of nano based seed treatment, the present study was planned to standardization of nano based selected insecticides for seed treatment on seed quality of Pigeonpea. 


\section{MATERIALS AND METHODS}

The laboratory experiments were conducted in the Seed Unit, University of Agricultural Sciences, Raichur, Department of Seed Science and Technology, University of Agricultural Sciences, Raichur and Nano Science and Technology laboratory, College of Agricultural Engineering, University of Agricultural Sciences, Raichur during 2016 to find out the standardization of nano based selected insecticides for seed treatment in Pigeon pea. The experiment were laid in Completely Randomized Design (CRD) consisted of 12 treatments viz., $\mathrm{T}_{0}$ : Absolute control $\mathrm{T}_{1}$ : Malathion $(5 \mathrm{~g} /$ $\mathrm{kg}$ of seeds), Fenvalerate $(4.0 \mathrm{~g} / \mathrm{kg}$ of seeds), Emamectin benzoate ( $40 \mathrm{mg} / \mathrm{kg}$ of seeds), Thiodicarb (2.7 mg/ $\mathrm{kg}$ of seeds), Sweet flag ( $20 \mathrm{~g} / \mathrm{kg}$ of seeds), Neem seed kernel powder $\left(5 \mathrm{~g} / \mathrm{kg}\right.$ of seeds), $\mathrm{T}_{2}:$ Nano Malathion $(5 \mathrm{~g} / \mathrm{kg}$ of seeds), Nano Fenvalerate $(4.0 \mathrm{~g} / \mathrm{kg}$ of seeds), Nano Emamectin benzoate $(40 \mathrm{mg} / \mathrm{kg}$ of seeds, Nano Thiodicarb $(2.7 \mathrm{mg} / \mathrm{kg}$ of seeds), nano sweet flag $(20 \mathrm{~g} / \mathrm{kg}$ of seeds), Nano Neem seed kernel powder $(5 \mathrm{~g} / \mathrm{kg}), \mathrm{T}_{3}$ : Nano Malathion, Fenvalerate, Emamectin benzoate, Thiodicarb, Sweet flag, Neem seed kernel powder@10\% less than the normal dosage, $\mathrm{T}_{4}$ : Nano Malathion, Fenvalerate, Emamectin benzoate, Thiodicarb, Sweet flag, Neem seed kernel powder@20\% less than the normal dosage, $\mathrm{T}_{5}$ : Nano Malathion, Fenvalerate, Emamectin benzoate, Thiodicarb, Sweet flag, Neem seed kernel powder @ 30\% less than the normal dosage, $\mathrm{T}_{6}$ : Nano Malathion, Fenvalerate, Emamectin benzoate, Thiodicarb, Sweet flag, Neem seed kernel powder@40\% less than the normal dosage, $\mathrm{T}_{7}$ : Nano Malathion, Fenvalerate, Emamectin benzoate, Thiodicarb, Sweet flag, Neem seed kernel powder@50\% less than the normal dosage, $\mathrm{T}_{8}$ : Nano Malathion, Fenvalerate, Emamectinebenzoat, Thiodicarb, Sweet flag, Neem seed kernel powder@60\% less than the normal dosage, $\mathrm{T}_{9}$ : Nano Malathion, Fenvalerate, Emamectin benzoate, Thiodicarb, Sweet flag, Neem seed kernel powder @ 70\% less than the normal dosage, $\mathrm{T}_{10}$ : Nano Malathion, Fenvalerate, Emamectin benzoate, Thiodicarb, Sweet flag, Neem seed kernel powder@80\% less than the normal dosage, $\mathrm{T}_{11}$ : Nano Malathion, Fenvalerate, Emamectin benzoate, Thiodicarb, Sweet flag, Neem seed kernel powder@90\% less than the normal dosage.

The different concentrations of nanoparticle seed treatment insecticides suspensions like were prepared for the experiment in distilled water. The nano insecticides were suspended directly in distilled water and dispersed by ultrasonic vibration $(100 \mathrm{~W}, 40 \mathrm{kHz})$ for 30 min. Small magnetic bars were placed in the suspension for stirring before use to avoid aggregation of the particles. Then the seeds are placed in the solution as per the required weight by volume ratio of seed to solution (1: 0.3). Seeds were air dried to original mois- ture content and then seed quality parameters were analysed. The observations on various seed quality parameters viz., seed germination (\%), root length $(\mathrm{cm})$, shoot length $(\mathrm{cm})$ seedling dry weight $(\mathrm{mg})$ were taken as per the ISTA procedure (Anonymous., 2013) and seedling vigour index were taken as per AbdulBaki and Anderson (1973). The mean data of the laboratory experiments were statistically analyzed by adopting completely randomized design as outlined by Panse and Sukhatme (1985). The critical differences were calculated at one per cent level of probability wherever ' $F$ ' test was found significant for various seed quality parameters under the study.

\section{RESULTS AND DISCUSSION}

Effect of nano malathion seed treatment on seed quality of Pigeon pea: Effect of nano malathion on seed quality of Pigeon pea seed is reported in Table 1. Seed treated with both macro and nano insecticides. Among the different concentration standardized nano malathion at 30 per cent reduction in its actual dosage $3.5 \mathrm{~g} / \mathrm{kg}$ of seed recorded significantly $(0.1 \%)$ the higher seed germination (98.00\%), lesser abnormal seedlings $(1.00 \%)$, with significantly higher shoot length $(10.13 \mathrm{~cm})$, root length $(12.56 \mathrm{~cm})$, seedling dry weight $(85.73 \mathrm{mg})$ and seedling vigour index (2223) over the other concentrations and control. The probable reason for enhanced physiological performance due to nano particles treatment could be attributed to the quenching of free radicals by the nano particles. Smaller size of the nanoparticles would have easily entered through cracks present on the outer seed surface, reacted with free radicals resulting in enhanced seed vigour. Sengupta et al., (2005) proved that finely powdered pharmaceutical formulation and crude plant materials got entry through cracks and crevices in the onion seed coat resulting in enhanced seed vigour.

Effect of nanofenvalerte seed treatment on seed quality of Pigeon pea: The seed treated with nano fenvalerate on seed quality of Pigeon pea seed is reported in Table 2. Among the different concentration standardized nano fenvalerate at 50 per cent reduction in its actual dosage $2.5 \mathrm{~g} / \mathrm{kg}$ of seed recorded significantly $(0.1 \%)$ the higher seed germination $(98.67 \%)$, lesser abnormal seedlings $(0.33 \%)$, with significantly higher shoot length $(9.00 \mathrm{~cm})$, root length $(12.93 \mathrm{~cm})$, seedling dry weight $(87.40 \mathrm{mg})$ and seedling vigour index (2164) over the other concentrations and untreated. Nano particles would induce oxidation-reduction reactions via the superoxide ion radical during germination, resulting the quenching of free radicals in the germinating seeds. In turn, oxygen produced in such process could also be used for respiration, which would further promote germination (Zhang et al., 2006).

Effect of nano thiodicarb seed treatment on seed quality of Pigeon pea: Effect of nano thiodicarb for- 
B.N. Raghu et al. / J. Appl. \& Nat. Sci. 9 (2): 1226 - 1235 (2017)

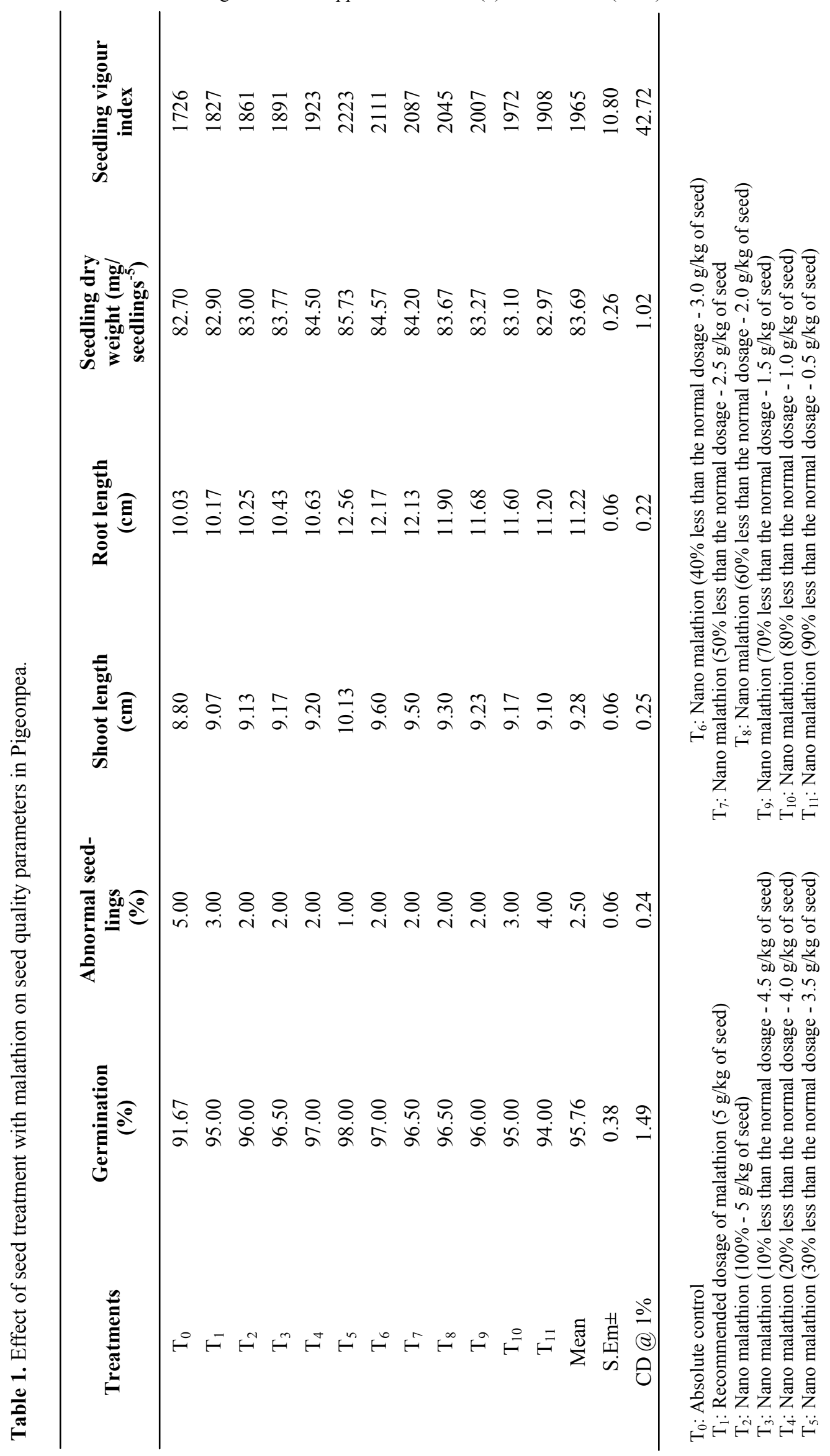




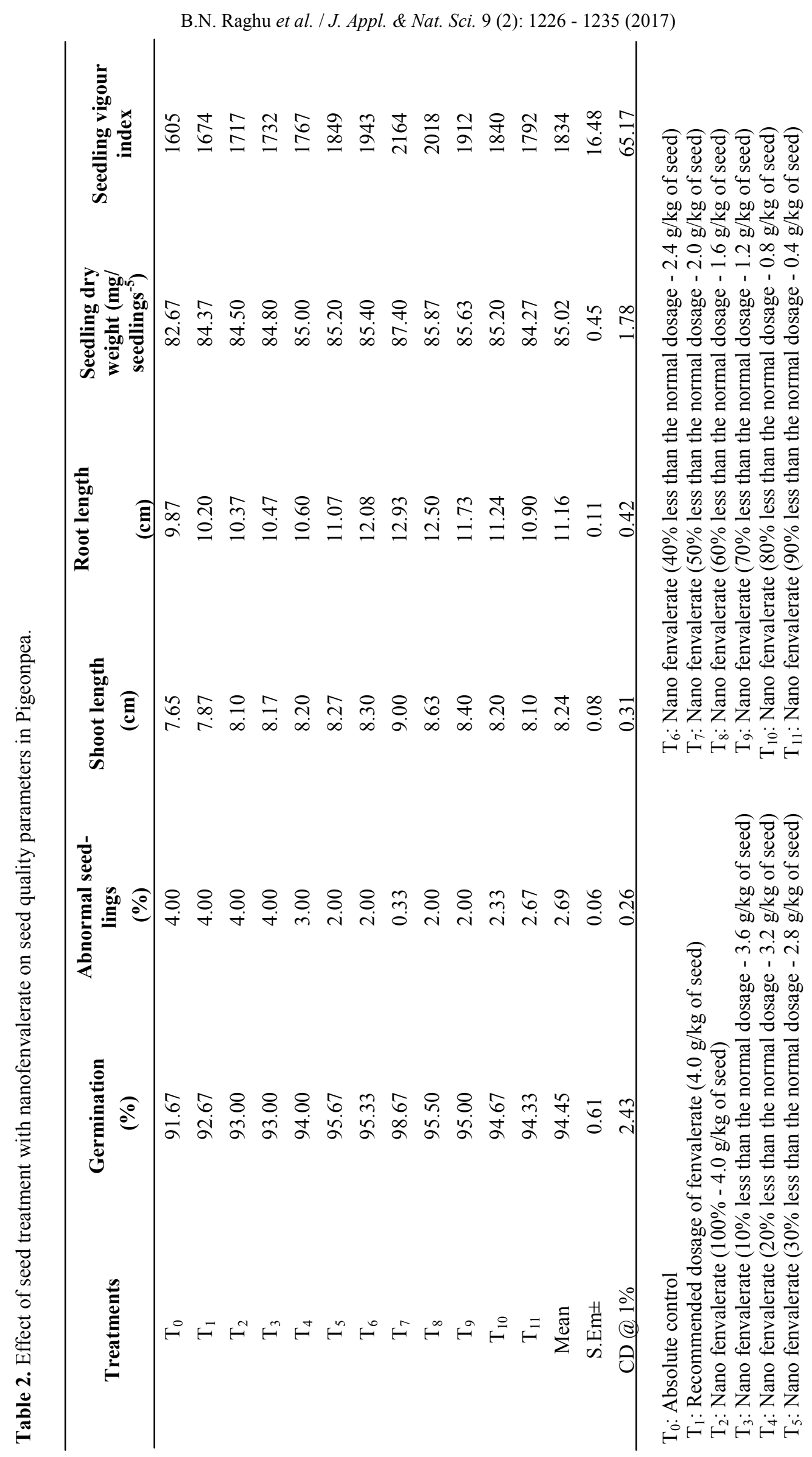




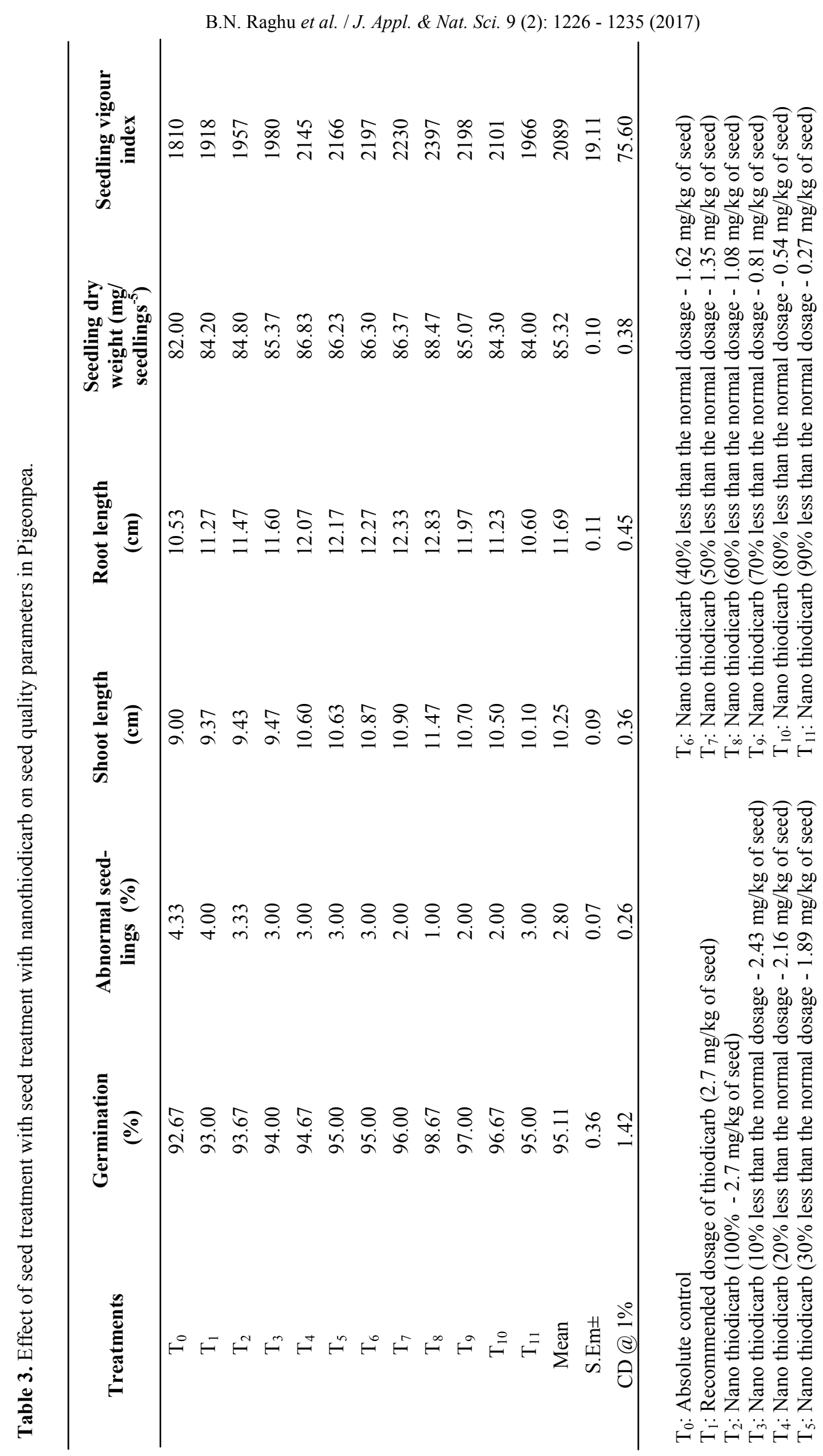


B.N. Raghu et al. / J. Appl. \& Nat. Sci. 9 (2): 1226 - 1235 (2017)

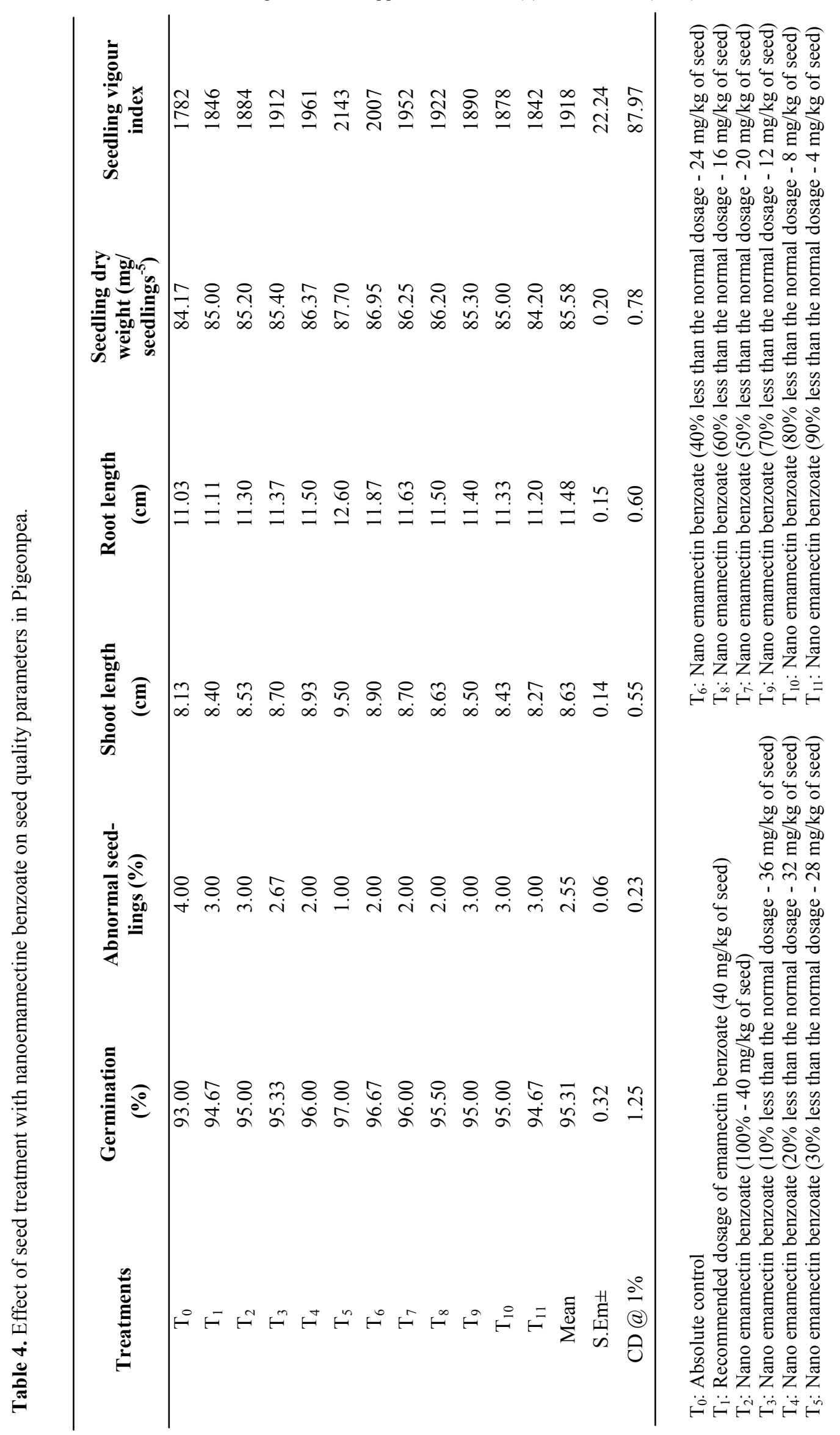




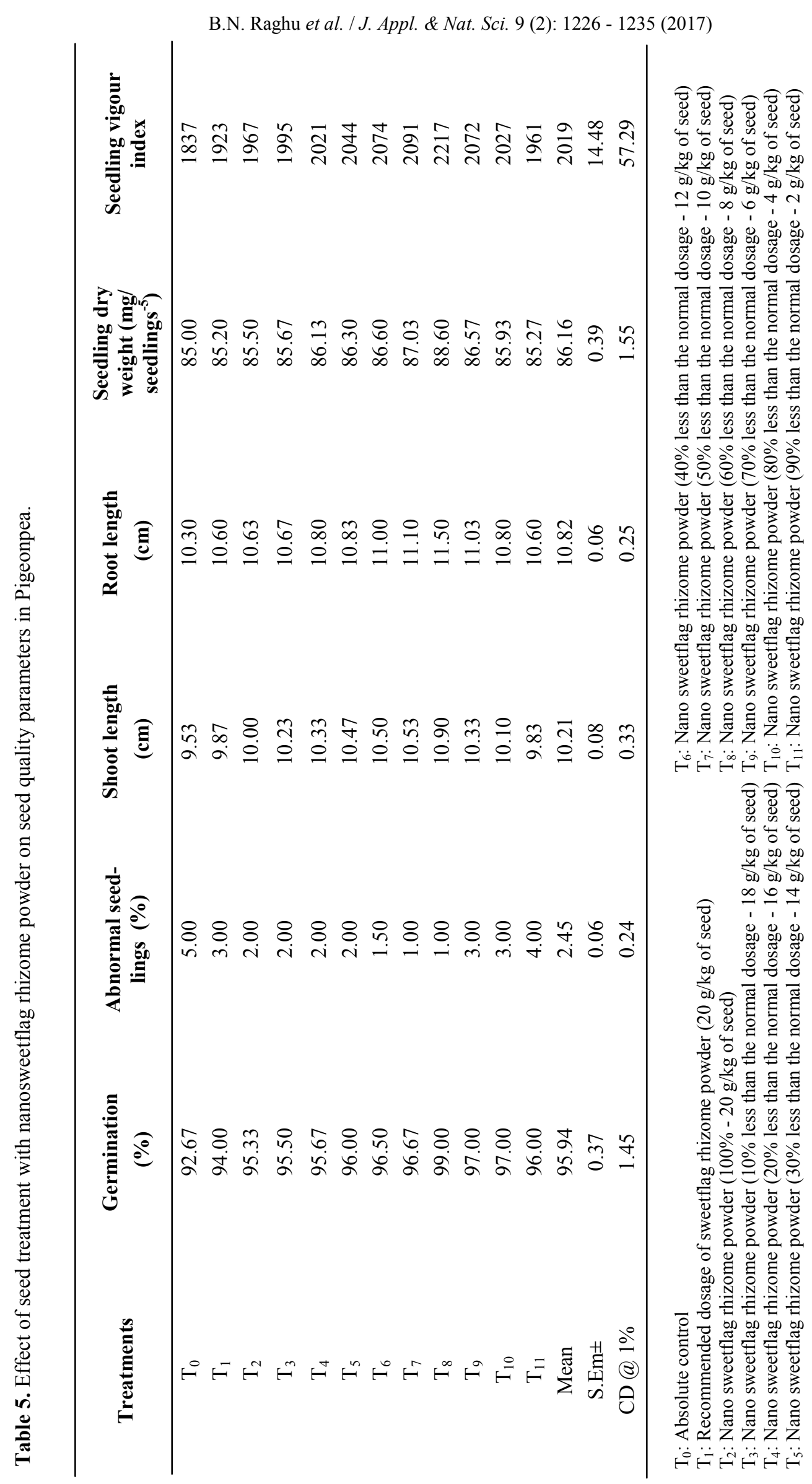


B.N. Raghu et al. / J. Appl. \& Nat. Sci. 9 (2): 1226 - 1235 (2017)

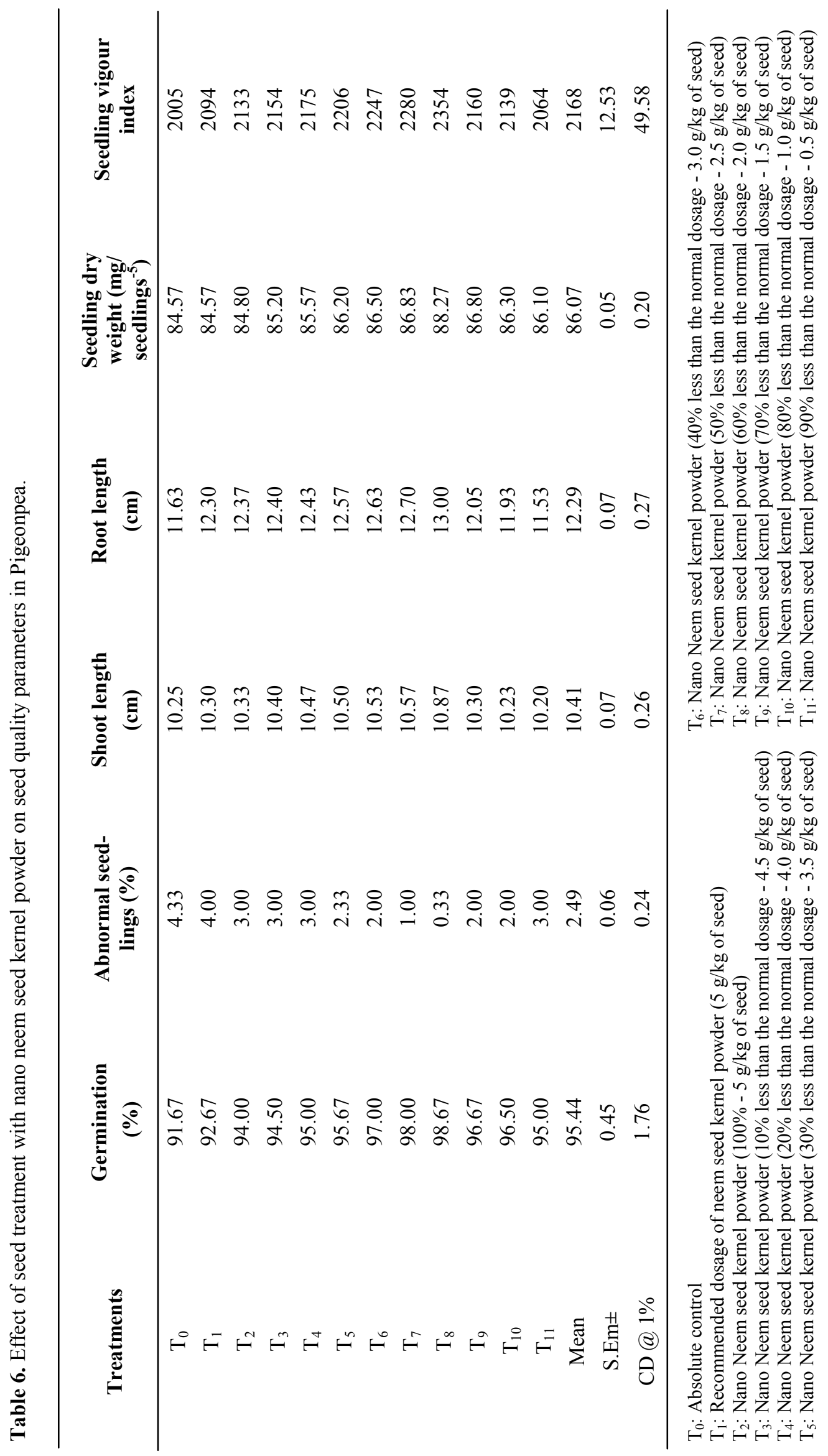


mulation on seed quality on Pigeon pea seed is reported in Table 4. The results showed that seed treatment with different concentrations, nano thiodicarb 60 per cent reduction in its actual dosage $1.08 \mathrm{mg} / \mathrm{kg}$ of seed recorded significantly the higher seed germination (98.67\%), lesser abnormal seedlings (1.00\%), with significantly higher shoot length $(11.47 \mathrm{~cm})$, root length $(12.83 \mathrm{~cm})$, seedling dry weight $(88.47 \mathrm{mg})$ and seedling vigour index (2397) over the other concentrations and control. The reason for rapid germination could be that the nanoparticles (NPs) may form new pores on seed coat during penetration facilitating the influx of water inside the seed or NPs may enter into the seed through the cracks present over the surface of the seed and activated the enzymes in early phase thereby enhanced the speed of germination. Similar results were also reported by Senthilkumar (2011) treatment with nanoparticles (Zinc oxide and zero valent iron particles upon wet and dry treatments) black gram seeds respectively.

Effect of nano emamectine benzoate seed treatment on seed quality of Pigeon pea: Effect of nano emamectine benzoate formulation on germination of Pigeon pea seed is reported in Table 3. Among the different concentration standardized, nanoemamectin benzoate at $30 \%$ reduction in its actual dosage $28 \mathrm{mg} /$ $\mathrm{kg}$ seed recorded significantly the higher seed germination $(97.00 \%)$, lesser abnormal seedlings (1.00\%), with significantly higher shoot length $(9.50 \mathrm{~cm})$, root length $(12.60 \mathrm{~cm})$, seedling dry weight $(87.70 \mathrm{mg})$ and seedling vigour index (2143) over the other concentrations and control. This increase in seed quality parameters could be ascribed to the increased synthesis and activity of hydrolytic enzymes during the early phases of germination and effective mobilization of the available food reserves in the seeds resulted in the early emergence and growth of the seedlings. In proportional to increase in seedling growth, dry matter production was also increased. These overall beneficial effects of NPs might be due to their increased chemical reactivity as cofactors of enzymes involved in seed germination and seedling growth. Avinash et al. (2010) in Cicer arietinum, found that NPs increased the level of IAA in the roots (sprouts) and thereby an increase in the growth rate of plants.

Effect of nano sweet flag seed treatment on seed quality of Pigeon pea: Among the different concentration standardized, nano sweet flag rhizome powder $60 \%$ reduction in its actual dosage $8.0 \mathrm{~g} / \mathrm{kg}$ of seed recorded significantly the higher seed germination (99.00\%), lesser abnormal seedlings (1.00\%), with significantly higher shoot length $(14.30 \mathrm{~cm})$, root length $(13.43 \mathrm{~cm})$, seedling dry weight $(88.60 \mathrm{mg})$, seedling vigour index (2785) over the other concentrations and control. The probable reason could be due to the excess absorption at higher concentration resulted from penetration of NPs in to cell wall and plasma membrane of epidermal layers in shoot and root and accumulation in vascular tissues thereby affected cell division and cell elongation. Hence, increased the overall seedling growth of pigeonpea. Similar results were also obtained by wet seed treatment with nanoparticles by Prasad et al.(2012) in ground nut, Azimi and Mohammad (2013) in Viciafaba., Adhikari et al. (2013) in rice, Mahmoodzadeh et al. (2013a) in wheat, Vinodh Kumar and Udaysoorian, (2014) in maize.

Effect of nano neem seed kernel powder seed treatment on seed quality of Pigeon pea: Data revealed that among the different concentrations of the macro and nano neem seed kernel powder, $60 \%$ reduction in its actual dosage $2.0 \mathrm{~g} / \mathrm{kg}$ of seed recorded significantly $(0.1 \%)$ the highest seed germination $(98.67 \%)$, lesser number of abnormal seedlings $(0.33 \%)$, with significantly higher shoot length $(10.87 \mathrm{~cm})$, root length $(13.00 \mathrm{~cm})$, seedling dry weight $(88.27 \mathrm{mg})$ and seedling vigour index (2354), this treatment performed better over different concentrations. Parsley wet seed treatment exposed to nanoanatase, enhanced germination, root and shoot length and chlorophyll content of the seedling, root elongation were promoted at a particular concentration ZnO NPs in soybean, seed germination, radicle and plumule growth of canola seedlings was stimulated by $\mathrm{TiO}_{2}$ NPs. Similar results were also observed by wet seed treatment by Dehkourdi and Mosavi (2013) in parsley, Lopez et al. (2010) in soyabean, Mahmoodzadeh et al. (2013) in canola seeds.

\section{Conclusion}

This increase in seed quality parameters could be ascribed to the increased synthesis and activity of hydrolytic enzymes during the early phases of germination and effective mobilization of the available food reserves in the seeds resulted in the early emergence and growth of the seedlings. In proportional to increase in seedling growth, dry matter production was also increased. These overall beneficial effects of NPs might be due to their increased chemical reactivity as cofactors of enzymes involved in germination and seedling growth.

It was found that nano insecticides treated seeds variously responded towards different concentrations in maintain seed quality of Pigeon pea, among the macro and nano insecticides, exhibited the best biological effects on Pigeon pea germination and vigour in comparison to the macro and control. Hence these nano based insecticides used for seed treatment in order to reduce the quantity of chemical required.

\section{REFERENCES}

Abdul-Baki, A.A. and Anderson, J.D. (1973). Vigour determination in soybean seeds by multiple criteria. Crop Sci., 13: 630-633

Adhikari, T., Kundu, S. and Subba Rao, A. (2013). Impact of $\mathrm{SiO} 2$ and Mo nanoparticles on seed germination of rice 
(Oryza sativa L). International. J. Agric. and Food Sci. Technol., 4(8): 809-816

Anonymous, (2013). International rules for seed testing, Seed Sci. and Technol., 27: 25-30

Avinash, C., Pandey, Sharda, S., Sanjay, Raghvendra. and Yadav, S. (2010). Application of ZnOnano particles in influencing the growth rate of Cicer arietinum. J. Exptl. Nano Sci., 5(6): 488-497

Azimi, R., Feizi, H. and Mohammad, K. (2013). Can bulk and nanosized $\mathrm{TiO}_{2}$ particles improve seed germination features of wheat grass (Agropyrondesertorum). Not. Sci. Biol., 5(3):325-331

Carmen, I.U., Chithra, P., Huang, Q., Takhistoy, P., Liu, S., Kokini, J. L. (2003). Nanotechnology: a new frontier in food science. Food Technol. 57: 24-29

Dehkourdi, E. H. and Mosavi, M. (2013). Effect of anatase nanoparticles $\left(\mathrm{TiO}_{2}\right)$ on parsley seed germination (Petroselinum crispum) in vitro. Biol.Trace Elements. Res., 155: 283-289

Hong, F., Yang, F., Liu, C., Gao, Q., Wan, Z., Gu, F., Wu, C., Ma, Z., Zhou, J. and Yang, P., (2005).Influ-ence of nano- $\mathrm{TiO}_{2}$ on the chloroplast aging of spin-ach under light. Biological Trace Element Res., 104: 249-260

Korishettar, P., Vasudevan, S. N., Shakuntala, N. M. Doddagoudar, S. R., Hiregoudar, S. and Kisan, B. (2016). Seed polymer coating with $\mathrm{Zn}$ and Fe nanoparticles: An innovative seed quality enhancement technique in pigeonpea. J. Applied Natural Sci., 8(1): 445450

Laurent, S., Forge, D., Port, M., Roch, A., Robic, C., van der Elst, L. and Muller, R. N. (2008). Magnetic iron oxide nanoparticles: synthesis, stabilization, vectorization, physicochemical characterizations and biological applications. Chem, 108: 2064-2110

Locke, J. M., Bryce, J. H. and Morris, P.C. (2000), effects of ethylene perception and biosynthesis inhibitors on germination and seedling growth of barley (Hordeum vulgare L.). Journal of Experimental Botany, vol, 51, Pp. 1843-1849

Lopez Moreno, M. L., De, L. R. G., Hernandez-Viezcas, J. A., Castillo-Michel, H., Botez, C. E., Peralta Videa, J. R. and Gardea, T. J. L. (2010). Evidence of the differential biotransformation and genotoxicity of $\mathrm{ZnO}$ and $\mathrm{CeO}_{2}$ nanoparticles on soybean (Glycine max) plants.
Environ Sci Technol., 44: 7315-7320

Mahmoodzadeh, H., Nabavi, M. and Kashefi, H. (2013). Effect of nanoscale titanium dioxide particles on the germination and growth of canola (Brassica napus), $J$ Ornamental Hortic Plants, 3: 25-32

Manchikanti P. and T. K. Bandopadhyay. (2010). Nanomaterials and effects on biological systems development of effective regulatory norm. Nanoethics, 4:77-83

Nel, A., Xia, T., Madler, L., Li, N. (2006). Toxic potential of materials at the 4. nano level. Science, 311(5761): 622627

Owolade, O. F., Ogunleti, D. O. and Adenekan, M. O. (2008). Titanium Dioxide affects disease Physiological and genetic analyses of aluminum tolerance in rice, focusing on root growth during germinations. J. Inorg. Biochem., 99. 1837-1844

Panse, V. G. and Sukhatme, P. V. (1985). Statistical methods for agricultural workers. ICAR Publication, New Delhi. p. 359

Prasad, K., Anal K. Jha. (2009). ZnO Nanoparticles, synthesis and adsorption study. Natural Science, 1: 129-135

Prasad, T. N. V. K. V., Sudhakar, P., Sreenivasulu, Y., Latha, P., Munaswamy, V., Raja Reddy, K., Sreeprasad. T. S., Sajanlal, P. R. and Pradeep, T. (2012). Effect of nanoscale zinc oxide particles on the germination, growth and yield of peanut. J. Plant Nutrition, 35(6): 905-927

Sengupta, A. K., De, B. K. and Mandal, A. K. (2005). Prestorage seed invigoration treatments for the maintenance of vigour, viability and field performance of high-vigour onion seed (Allium cepa L.). Seed Sci. Technol., 33(3): 753-760

Senthilkumar, S. (2011). Customizing nanoparticles for the maintanence of seed vigour and viability in Blackgram (Vigna mungo) cv. VBN 4. M.Sc. Thesis, Tamil Nadu Agricultural University, Coimbatore (India).

Vinodh Kumar, S. and Udayasoorian, K. (2014). Toxicity potential of different metal oxides nanoparticles on germination of maize plant. Global J. Res. Analysis, 3(1): 116-118

Zhang, L., Hong, F., Lu, S. and Liu, C. (2005). Effect of nano- $\mathrm{TiO}_{2}$ on strength of naturally aged seeds and growth of spinach. Biol. Trace Elem. Res., 106: 279-297 